\title{
Testing the Beneish Model Relevance in Case of Entities with Confirmed Reputational Risk
}

\author{
Ioan-Ovidiu Spătăcean ${ }^{1 *}$
}

\begin{abstract}
${ }^{1}$ Faculty of Economics and Law, EDl Department - Economic Sciences, University of Medicine, Pharmacy, Sciences and Technology "George Emil Palade" from Targu Mures, Gh. Marinescu Street, no. 38, Targu Mures, 540139, Romania
\end{abstract}

\begin{abstract}
The Beneish model is a useful tool for assessing the potentially fraudulent behaviour of an entity that could resort to misstated financial reporting by manipulating earnings. Tarjo \& Herawati (2015) concluded that "the M-score of the Beneish model was generally able to detect financial fraud", following a study on 35 listed companies that were confronted with allegations of fraud in the period 2001-2014, by accessing the sanctions database applied to companies of public interest (issuers) published by the Financial Supervisory Authority. Also, Ahmet Ozcan (2018) stated that the Beneish model "brings effective value in the analysis of the quantitative characteristics of falsified financial statements", a conclusion based on a concentrated research on a sample of 174 firms over the period 2005-2017. However, the construction of this model was not oriented for the financial services industry, therefore the studies referred to above do not include any investment firms. Our research aims to assess the relevance of the use of the Beneish model to entities involved in scandals on fraudulent or suspected distorted financial reporting operations (Romcab, 2017 and Harinvest, 2013) in order to Test the Beneish model's validation capability. On the basis of the conclusions obtained, it can be accepted that the applicability of the model is validated for the entities examined.
\end{abstract}

Keywords: earnings management, investment firm, Beneish m-Score, fraudulent reporting, reputational risk

JEL Classification: M41, M42, G41

(C) 2019 Publised by ACTA MARISIENSIS, SERIA OECONOMICA, Publisher University Press Târgu Mureș, issued on behalf of University of Medicine, Pharmacy, Sciences and Technology "George Emil Palade" from Tîrgu Mureș, România

\footnotetext{
${ }^{*}$ Corresponding author: Ioan-Ovidiu Spătăcean

e-mail: ovidiu.spatacean@umfst.ro
} 


\section{INTRODUCTION}

Fraudulent financial reporting is a problem of high interest, equally for the regulators of financial markets who are constantly concerned about protecting the integrity of markets and investor confidence in its mechanisms, but also for investors, as their capital providers. risk allocated to investments in marketable financial instruments.

Some cases of notoriety for the recent history of the Romanian capital market (Harinvest 2013 or Romcab 2017) have had a negative impact on the investors' perception regarding the safety of the funds placed in the custody of an authorized and regulated intermediary, respectively in the financial instruments tradable on a regulated market. In both cases, the common denominator was limited to the losses registered by the investors, as follows: losses estimated at EUR 3.5 million for approximately 72 investors in the case of Harinvest (Spătăcean O., 2017) and a depreciation of the trading price by almost $80 \%$ between January and February 2017 for the shares of the Romcab issuer (MCAB symbol).

The literature contains several models for predicting fraudulent behavior in financial reporting, most of them based on the analysis of financial rates and their compilation as a scoring function. Among them, the model Beneish (1999) was able to successfully detect issues compatible with fraudulent reporting by manipulating income, which were later confirmed in a resounding bankruptcy case in 2001, the case of Enron.

\section{DEFINING THE RESEARCH PROBLEM}

Professor Messod Beneish proposed a mathematical model for identifying entities that manipulate reported earnings, as well as the circumstances that may cause such entities to engage in fraudulent financial reporting practices. In substantiating the model, the assumption was accepted that the probability associated with the risk of fraudulent reporting can be significantly increased as an unusual increase in receivables and sales or a decrease in the gross operating margin is recorded. The Beneish model uses financial information for the purpose of determining eight variables that generate a function $\mathrm{M}$-score against which the probability that the reported results have been distorted for the purpose of earnings manipulation is measured. According to the model, the probability of manipulation is correlated with:

- an unusual increase in net receivables (Days' Sales in Receivables). According to the model, there is a reasonable assumption that the significant increase in sales could be the result of a change in the commercial lending policy, causing an increase in the likelihood that the recorded revenue would have been overvalued;

- a deterioration of the gross margin (Gross Margin Index). In general, such an evolution has a negative effect on the going concern, in such circumstances there is a reasonable possibility that the management may be tempted to distort the financial reporting, in order to respond on debt clauses or to meet the expectations of investors in terms of return on investment;

- an asset quality impairment (Asset Quality Index). Estimating the capability to recovery the book value of an entity's assets is an important problem of professional judgement. To the extent that the entity holds tangible fixed assets, inventories, receivables and financial investments exposed to a high degree of impairment, its performance could be significantly affected, in which case management may resort to financial information manipulation techniques; 
- a downsize in sales and sustainable growth (Sales Growth Index). The increase of this variable does not necessarily imply the existence of a manipulation, but the companies that register significant increases are examined with more caution;

- a significant variation in depreciation of fixed assets (Depreciation Index). A lower rate of depreciation in comparison with the one estimated according to the rate at which the economic benefits generated by the assets are consumed, may signal that the reporting entity explores new methods of increasing the income and implicitly of improving the financial performance;

- a significant variation in general-administrative and sales expenses (SGA Index). A disproportionate increase of these expenses in relation to the evolution of sales is a negative signal for the financial perspectives of a reporting entity, facilitating transfers of resources under disadvantageous conditions, under the form of external benefits;

- an adverse change in the financial condition of the entity (Leverage Index). This evolution is also a negative signal in appreciating an entity's ability to continue operations under normal business conditions. An increase in the financial leverage may put pressure on future cash flows, but it could also force management to resort to a distortion in financial reporting, in order not to increase creditors' suspicions;

- a significant variation in the ratio of deferred income to total assets (Accruals to Assets Index). The indicator is calculated as the difference between operating income and cash from operating activity, divided to total assets. This financial variable measures the extent to which managers use discretionary accounting options to manipulate earnings.

These eight financial variables are integrated into a score function on the basis of which anomalies or suspicions regarding earnings manipulation can be assessed. For values lower than (-) 2.22 it is assumed that a reporting entity is not involved in earnings manipulation operations, while a value greater than this threshold could suggest the opposite ${ }^{\dagger}$.

\section{PRESENTING THE RESEARCH FINDINGS}

To test the relevance of the Beneish model, the M score was determined for the Romcab S.A. issuer (MCAB symbol), which was suspended from trading on 17.02.2017 for the purpose of presenting a detailed report on the significant change in the financial situation during the fourth quarter of 2016, after which the insolvency procedure was opened (22.02.2017). The values of the $\mathrm{M}$ score were calculated based on the annual financial statements published between 2014 and 2016 and are presented in Table no. 1.

The values recorded by the $\mathrm{M}$ score in each of the three reporting periods are positive, specific to a reporting entity suspected of distorted financial statements by the manipulation of income, in the acceptance of the Beneish model. The value determined on the basis of the financial statements for 2016 is significantly higher compared to the previous year $(+131 \%)$,

\footnotetext{
$\dagger$ The description of the mathematical formulas for computing the eight financial variables, including the score function, can be found at https://en.wikipedia.org/wiki/Beneish_M-Score
} 
amplifying the profile of a possible corporate behavior engaged in profit manipulation. Other warning signs in this direction could have been related to: the liquidation of the $20 \%$ holding in the MCAB issuer by the Morgan Stanley investment fund; the unusually high growth of inventories in the period 2013-3014 (four times) compared to doubling the turnover (operating income) in the same period; a significant number (over 100) of payment incidents between December 2016 and January 2017; omission to publish current reports on 14 relevant litigations that occurred during 2016, including to recognize provisions in accordance with applicable accounting principles; excessive risky behavior regarding the debt (the intention to launch a EUR 200 million bond issue in January 2017). In these circumstances, we appreciate that the Beneish model has confirmed a specific behavior of an entity possibly engaged in earnings manipulation operations ${ }^{\ddagger}$.

Table no. 1 - M-Score values for the issuer Romcab S.A.

\begin{tabular}{|c|c|c|c|}
\hline Financial ratios & 31.12.2016 & 31.12.2015 & 31.12.2014 \\
\hline Days Sales in Receivables Index (DSRI) & 1.23 & 1.16 & 0.63 \\
\hline Gross Margin Index (GMI) & 1.38 & -0.58 & -0.31 \\
\hline Asset Quality Index (AQI) & 1.19 & 0.64 & 0.97 \\
\hline Sales Growth Index (SGI) & 1.14 & 1.24 & 1.42 \\
\hline Depreciation Index (DEPI) & 0.86 & 0.86 & 0.57 \\
\hline Sales General and Administrative Expenses Index (SGAI) & 1.18 & 1.08 & 1.76 \\
\hline Leverage Index (LVGI) & 1.24 & 0.99 & 1.03 \\
\hline Total Accruals to Total Assets (TATA) & -0.21 & -0.02 & -0.02 \\
\hline Beneish M-Score & 4.28 & 1.85 & 1.84 \\
\hline
\end{tabular}

Source: Author's projection

In the case of the Harinvest investment firm, the values of the $\mathrm{M}$ score were determined based on the annual financial statements published for the period 2010-2012. The results are summarized in Table no. 2.

As in the case of $\mathrm{MCAB}$, the values of the $\mathrm{M}$ score were positive during the analyzed financial reporting periods, with a significant increase $(+147 \%)$ in the year preceding the entry into insolvency / bankruptcy. Warning signals that could have anticipated fraudulent behavior are related to: a major exposure on the structured products market, in the absence of own funds needed for house trading; a significant number of sell-out transactions, or serious inconsistencies in the annual financial statements (2012) associated with major vulnerabilities in ensuring the segregation and security of the clients' assets.

\footnotetext{
\# These presumptions are also supported by the submission by the Financial Supervisory Authority of a criminal complaint in the Romcab case, being notified to the DIICOT prosecutors and ANAF inspectors, according to media articles published in February 2017 (https://www.smartbeta.ro/2017/02/asf-a-depus-la-diicot-si-anaf-plangerepenala-in-cazul-romcab/, https://ardealnews.ro/2018/02/19/diicot-vrea-sa-afle-unde-au-disparut-banii-de-la-romcabtirgu-mures/). The investigations concern the offense provided in art. 134, para. (1) of Law 24/2017, respectively "the intentional presentation [...] of inaccurate financial statements or non-accurate information regarding the economic conditions of the issuer".
} 
Table no. 2 - M-Score values for Harinvest S.A. investment firm

\begin{tabular}{|r|c|c|}
\hline Financial ratios & $\mathbf{3 1 . 1 2 . 2 0 1 2}$ & $\mathbf{3 1 . 1 2 . 2 0 1 1}$ \\
\hline Days Sales in Receivables Index (DSRI) & 3.34 & 0.53 \\
\hline Gross Margin Index (GMI) & -1.18 & -1.61 \\
\hline Asset Quality Index (AQI) & 0.87 & 0.89 \\
\hline Sales Growth Index (SGI) & 1.13 & 2.57 \\
\hline Depreciation Index (DEPI) & 0.81 & 2.06 \\
\hline Sales General and Administrative Expenses Index (SGAI) & 0.80 & 0.50 \\
\hline Leverage Index (LVGI) & 1.27 & 0.93 \\
\hline Total Accruals to Total Assets (TATA) & 0.41 & 0.10 \\
\hline Beneish M-Score & $\mathbf{4 . 7 5}$ & $\mathbf{1 . 9 2}$ \\
\hline
\end{tabular}

Source: Author's projection

We also find a validation of the fraudulent behavior in the case of the intermediary Harinvest SA, by reference to the values obtained for the $M$ score from the Beneish model ${ }^{\S}$. In case of other Romanian investment firms (a sample of 14 resident investment firms, with a market share of more than $1 \%$ ), the tests performed on the financial reports for the period 20162018 have shown extremely controversial results. Thus, more than half of the investment firms examined registered values that could suggest fraudulent behavior in terms of income manipulation, a slightly credible scenario considering the proactive involvement of the Financial Supervisory Authority through prudential monitoring and supervision of financial reports.

\section{CONCLUSIONS}

Based on the tests performed, we concluded that the Beneish model confirmed a manipulative behavior, through the values recorded by the $\mathrm{M}$ score, mainly based on the financial statements for the reporting year preceding the entry into the insolvency procedure. These validations have been reinforced by other warning signals associated with corporate behavior outside the regulatory framework and ethical requirements specific to good governance. In the case of entities in the financial services industry, the application of the model is not appropriate, since the results obtained are not conclusive.

\section{Bibliography:}

Ahmet O. (2018). The Use of Beneish Model in Forensic Accounting: Evidence from Turkey, Journal of Applied Economics and Business Research, 2018, ISSN 1927-033X;

Beneish M. (1999). The Detection of Earnings Manipulation.

Rasa K., Zivile G (2015). The Model of Fraud Detection in Financial Statements by Means of Financial Ratios, Procedia Social and Behavioral Sciences, Elsevier Ltd., 2015, ISSN 1877-0428;

\footnotetext{
$\S$ In the case of Harinvest SA, the Financial Supervisory Authority notified DIICOT regarding suspicions regarding the manipulation of the capital market and falsified reports to the Central Depository.
} 
Spătăcean O. (2017) The Impact of Corporate Governance Failure for Investment Firms Harinvest Case, Revista Studia Universitatis Petru Maior Series Oeconomica, Fasciculus 1, 2017, ISSN 1843-1127, ISSN online 2286-3249;

Stephen A., Arnie W., Zimbelman M. (2015). Challenges Facing Auditors in Detecting Financial Statement Fraud: Insights from Fraud Investigations, Journal of Forensic \& Investigative Accounting, vol. 7, Issue 2.

Tarjo, N. H. (2015). Application of Beneish M-Score Models and Data Mining to Detect Financial Fraud, Procedia Social and Behavioral Sciences, Elsevier Ltd., ISSN 1877-0428. 